\title{
Humanist Methods in Natural Philosophy: The Commonplace Book
}

\section{Citation}

Blair, Ann. 1992. Humanist methods in natural philosophy: The commonplace book. Journal of the History of Ideas 53(4): 541-551.

\section{Published Version}

http://dx.doi.org/10.2307/2709935

\section{Permanent link}

http://nrs.harvard.edu/urn-3:HUL.InstRepos:3373452

\section{Terms of Use}

This article was downloaded from Harvard University's DASH repository, and is made available under the terms and conditions applicable to Other Posted Material, as set forth at http:// nrs.harvard.edu/urn-3:HUL.InstRepos:dash.current.terms-of-use\#LAA

\section{Share Your Story}

The Harvard community has made this article openly available.

Please share how this access benefits you. Submit a story.

\section{Accessibility}




\section{Humanist Methods in Natural Philosophy: the Commonplace Book}

Ann Blair

As new evidence for the interaction between humanism and science in the Renaissance I will trace the use among natural philosophical authors of a quintessentially humanist method of reading and storing information-through the commonplace book. In this method of reading (which I will call the method of commonplaces) one selects passages of interest for the rhetorical turns of phrase, the dialectical arguments, or the factual information they contain; one then copies them out in a notebook, the commonplace book, kept handy for the purpose, grouping them under appropriate headings to facilitate later retrieval and use, notably in composing prose of one's own. Strictly defined the commonplace book is a humanist innovation, but like most Renaissance practices it adapted a concept with a glorious ancient pedigree to suit contemporary, in this case pedagogical, needs. Ancient rhetoric, from Aristotle's Topics to Quintilian's Institutio oratoria, had developed a list of the places or loci of use to the orator: including "seats of arguments" (from effects, from circumstances, from greater or lesser, for example) and rhetorical embellishments (amplification, captatio benevolentiae, and so on). In the Middle Ages florilegia and sermon manuals supplemented those theoretical guides to good arguing with substantive material which could be copied directly: moral sentences or in the case of medical handbooks, "commonplace" medical recipes, compiled for easy access. ${ }^{1}$

In the Renaissance the notion of "place" continued to expand, as pupils throughout Europe were taught to keep their own commonplace books while in school and afterwards through a lifetime of reading. Guarino da Verona, Erasmus, and Vives among other pedagogues wrote specific instructions for keeping such notebooks. Alongside memorable rhetorical idioms the commonplace book was to record, often in a separate

${ }^{1}$ Sister Joan Marie Lechner, Renaissance Concepts of the Commonplaces (New York, 1962), 62, on medical compilations. 
notebook, a wide range of realia or interesting bits of general information sorted under appropriate subject headings according to the topics and themes addressed. ${ }^{2}$ Travellers in particular were admonished to keep notebooks of this kind to record all the things that they encountered. ${ }^{3}$ The commonplace book thus encompassed all the aspects of inventio, or the gathering of material for an argument, and became the crucial tool for storing and retrieving the increasingly unwieldy quantity of textual and personal knowledge that guaranteed copiousness in speech and writing. The commonplace book thus spread as widely in Renaissance Europe as the Erasmian ideal of eloquence through copia rerum or abundance of material. ${ }^{4}$ Historians of literature have indeed amply shown how minor and major literary figures, most notably Shakespeare and Montaigne, relied for their writing on commonplace books, both on personal notebooks and on the printed cribs designed to supplement (or in the case of the lazy writer, to replace) them. ${ }^{5}$

What is less well known and what I will argue here is that natural philosophical writers in the sixteenth and early seventeenth centuries relied equally heavily on books of commonplaces, specifically natural commonplaces. Miy main example will be a little-known encyclopedia of natural philosophy, the Universae naturae theatrum (Theater of all nature) first published in 1596 by the French political philosopher Jean Bodin. ${ }^{6}$ Bodin is primarily known for his theory of sovereignty expounded in his Six livres de la république (1576), for his rabid manual of witchhunting or Démonomanie (1580), and for his elusive position on religious toleration associated with a work left in manuscript, the Colloquium heptaplomeres. ${ }^{7}$

${ }^{2}$ Zachary Schiffman, "Montaigne and the Rise of Skepticism in Early Modern Europe: A Reappraisal," JHI, 45 (1984), 504-5.

${ }^{3}$ See for example J. H. Alsted: "Qui peregrinatur, conficiet sibi adversaria, in quibus obvia via quaeque consignabit. Domum reversus singula rediget in certum ordinem. Qui certo in loco commoratur, sequentes monitiones notabit." Orator (Herborn, 1616), 302-3.

${ }^{4}$ Terence Cave, The Cornucopian Text: Problems of Writing in the French Renaissance (Oxford, 1979), section I, ch. 1.

${ }^{5}$ See for example T. W. Baldwin, William Shakspere's Small Latine and Lesse Greeke, 2 vols. (Urbana, 1944). On Montaigne, see Francis Goyet, "A propos de 'ces pastissages de lieux communs' (le rôle des notes de lecture dans la genèse des Essais)," Bulletin de la Sociéte des Amis de Montaigne, 5-6 (1986), 11-26, and 7-8 (1987), 9-30. I am grateful to Francis Goyet for useful conversations about commonplaces in the Renaissance, on which he is preparing a French thèse d'etat. One example of a printed commonplace book is Theodor Zwinger's Theatrum vitae humanae (1565), on which see Walter J. Ong, "Commonplace Rhapsody: Ravisius Textor, Zwinger and Shakespeare," in R. R. Bolgar (ed.), Classical Influences on European Culture 1500-1700 (Cambridge, 1976), 91-126.

${ }^{6}$ There is unfortunately no complete intellectual biography of Jean Bodin since René Chauviré, Jean Bodin, auteur de la République (La Flèche, 1914); for a recent study of his later thought see Paul Lawrence Rose, Bodin and the Great God of Nature (Geneva, 1980).

${ }^{7}$ These texts are easily available: Six Livres de la République (Lyon, 1593) reprinted (Paris, 1986); De la Démonomanie des sorciers (Paris, 1587) in facsimile (Paris, 1984); 
But Jean Bodin was also a humanist, author of a Latin translation with commentary of Oppian's Cynegetica (On the hunt, 1555), and of a Method for the easy comprehension of history (or Methodus, 1566). ${ }^{8}$ Finally, he was a natural philosopher: the Theatrum is a 633-page work of physics (in Bodin's own words) which discusses the natural world from its first principles through the stages of the chain of being-rocks and metals, plants and animals, souls, angels and heavenly bodies. ${ }^{9}$ The Theatrum appeared soon after its publication on the reading lists of university professors of natural philosophy in the German-language area, which is sufficient evidence that, although today we consider Jean Bodin almost exclusively for his political philosophy, his Theatrum was read and perceived by contemporaries as a significant contribution to natural philosophy. In tracing how Bodin used his sources and how his work was used in turn by its readers we can follow traditional natural philosophy in the making through a seemingly unending cycle of textual selection and assessment which the method of commonplaces can usefully illuminate.

The evidence for Bodin's use of a book of natural commonplaces in composing the Theatrum is only indirect: Bodin provides almost no discussion of his methods in the Theatrum; furthermore no autograph manuscripts survive. ${ }^{10}$ We cannot know, therefore, exactly what form Bodin's notebook might have taken: how many entries, of what type, accumulated over how many years and so on. Bodin's use of such a notebook seems quite probable, however, not only because the method was widely taught in Renaissance schools but also because Bodin seems to have followed his own precepts enounced in the Methodus of 1566. In chapter 3 entitled "how properly to establish the places of histories" Bodin explains:

The abundance and variety of histories is so great that they cannot be clearly understood nor retained in the memory for long unless they are distributed into certain established categories. ... So for that reason I think we must follow this order in providing an account of all places in three books: in the first of human matters; in the second of the natural events that happen often in history; in the third of divine things.

Colloque entre sept sçavans. .. , ed. François Berriot (Geneva, 1984) and Colloquium of the Seven. . . , tr. Marion L. Kuntz (Princeton, 1975).

${ }^{8}$ See Bodin, Cynegetica (Paris, 1555); Methodus ad facilem historiarum cognitionem, ed. and tr. Pierre Mesnard in Oeuvres philosophiques de Jean Bodin (Paris, 1951), English translation by Beatrice Reynolds (New York, 1945). Unless otherwise specified all translations are my own.

${ }^{9}$ For a study of this work see Ann Blair, "Restaging Jean Bodin: the Universae naturae theatrum in its Cultural Context" (Ph.D. dissertation Princeton University 1990 and forthcoming Princeton University Press).

${ }^{10}$ For a bibliography of Bodin's extant writings see Roland Crahay, Marie-Thérèse Isaac and Marie-Thérèse Lenger, Bibliographie critique des éditions anciennes de Jean Bodin (forthcoming). 
Bodin goes on to describe these commonplace books in more detail, in particular:

The second book will embrace with the appropriate divisions the histories of the natural things which occur most often in reading historians: first on the principles of nature, on time and place, birth and death, and motion and change more generally; on the elements and their nature; on imperfect bodies, metals and stones; on the genus of plants, on animals divided into three orders, on the celestial bodies, on the shape and size of the world. ${ }^{11}$

That is, at an interval of thirty years, an excellent description of the Theatrum.

Like a commonplace book, the Theatrum is an aid to the memory: its title evokes contemporary memory theaters, and Bodin's Theatrum can be interpreted as a bookish contribution to that tradition ${ }^{12}$ Bodin explicitly adopts the form of a dialogue between master and pupil "because nothing is more efficacious for the memory."13 Secondly, like the commonplace book that Bodin describes, the Theatrum is about the natural things "that happen fairly often in history" or "that occur fairly often in reading historians." 14 Bodin's purpose is to make natural philosophy out of natural history by offering new causal explanations for a myriad natural "facts" culled from his reading. Why is the goat dumbfounded by eating an eryngius plant? (294) Why is a smaller seed more potent than a larger one? (276) The facts embedded in these questions appear in the natural histories of Pliny and Theophrastus respectively ${ }^{15}$ evidently for Bodin they are already so well established by virtue of their being asserted there that they do not need to be stated in the Theatrum before they are explained. The goat is dumbfounded by the eryngius plant because of a natural antipathy, and smaller seeds are more potent than larger ones not, as Theophrastus claimed, because they are formed more rapidly but because their virtue is more concentrated. The explananda have become "commonplaces" in the technical as well as the colloquial sense: in being selected from their original source and entered into the commonplace book they have become self-evident truths. Bodin's task then is to create natural philosophical knowledge by providing causal understanding of these undisputed facts.

${ }^{11}$ Jean Bodin, Methodus, in Pierre Mesnard, Oeuvres philosophiques, 119, 122.

${ }^{12}$ See Frances Yates, The Art of Memory (Chicago, 1966).

${ }^{13}$ Jean Bodin, Universae naturae theatrum, 2nd ed. (Frankfurt, 1597), 7. All further references to this work will be given in parentheses in the text.

${ }^{14}$ History and the accounts of historians seem here to be interchangeable for Bodin, in a kind of conflation which is analogous to his confusion of nature and natural philosophy in the prefatory praise of the Theatrum. I argue that this slippage reveals Bodin's assumption that the textual representation of nature, or history, is transparent.

${ }^{15}$ Pliny, Natural history, VIII, ch. 50, also Plutarch, Moralia, "De sera numinis vindicta," 558E; Theophrastus, De causis plantarum, II, ch. 17. 
Bodin uses the commonplace book as an arsenal of "factoids," tidbits of knowledge which he divorces from their original context in order to suit his own purposes. In his lifetime Bodin was reputed for the abundance of beautiful things (pulcherrimarum rerum copia) that he could command in conversation; ${ }^{16}$ his writings also display the range and depth of his notebooks. In the Theatrum Bodin draws on his wide reading which is perhaps not as wide, however, as the 250 authors whom he cites by name would suggest: many of these citations were no doubt culled from an intermediate source which became invisible when they passed through the commonplace book, as I am able to demonstrate in a few cases. ${ }^{17}$ Bodin also includes direct personal experience; for example, an observation from his daily life as a student in Toulouse that salt water fish are larger and have more taste than fresh water fish, a fact that he uses to show that salt water is purer than fresh water (333), or an observation that required motivated investigation, of a 20-cubit crocodile, which he contrasts with the no doubt bookish fact that terrestrial crocodiles do not exceed three cubits, this time to show the greater fertility of water over air (394). Bodin gathers information from acquaintances like one "Alacris" of Clermont who showed him wood that had petrified while floating in a certain fountain in the center of France (228) and, in a uniquely Renaissance fashion, from consulting with practitioners of various manual professions (see for example the description of the sauna below). The commonplace book thus accumulates "facts" from an indefinitely large and disparate range of sources and treats each fact, whether traditional or of recent origin, bookish or directly observed, as equivalent to every other. Bodin specifies cases of personal experience but not in order to stress the greater validity of directly observed over bookish knowledge ${ }^{18}$ rather Bodin consistently mentions those sources, including bookish ones, which fall outside the ordinary canon of classical texts and with which his reader would probably not be familiar.

The flexibility of the dialogue form allows the Theatrum to follow the structure of the commonplace book and to combine the two conflicting organizational principles of topic and theme. The headings in the com-

\footnotetext{
${ }^{16}$ See the comment by de Thou as quoted in Pierre Bayle, Dictionnaire historique et critique, "Bodin," note (E), also reprinted in Pierre Mesnard, Oeuvres philosophiques, xxvii.

${ }^{17}$ For example a list of Thomist doctors cited on the question of the location of angels ("Durandus et Bernardus de Guagnaco in impugnationibus, Henr. quolib. 2., Thomas Anglicus in quolib., Henr. [sic for Herv.] Brito in 2. sentent., Ioan. Paris. in Correctorio" Theatrum, 514) is lifted from Pico della Mirandola, Apologia in Opera omnia (Basel, 1567), I, 128-29. I am grateful to Jean Céard for help in tracking down this source.

${ }^{18}$ This attitude contrasts with that of the early experimenters who boasted of their superior reliability and of that of their witnesses; cf. Peter Dear, "Totius in verba: the Rhetorical Constitution of Authority in the Early Royal Society," Isis, 76 (1985), 145-61; or Steven Shapin and Simon Schaffer, Leviathan and the Air-Pump: Hobbes, Boyle and the Experimental Life (Princeton, 1985).
} 
monplace book can vary indefinitely and arbitrarily: those which Bodin suggested in the Methodus were primarily topical (elements, plants, animals, and so on), and in broad outline the Theatrum follows the topics and order specified there, ascending the chain of being step by step. But the way in which Bodin brings together topically unrelated material in adjacent questions or within the answer to one question suggests that he also used thematic headings, a practice that was commonly advocated, along with cross-references or multiple entries of the same material under different headings. Bodin can thus gather entries under a thematic heading to pursue a general pattern of nature; for example, when he sets out to explain why the heat of the summer is greater in areas on either side of the tropics than in the tropics themselves, although the rays of the sun are more oblique there. He first establishes the fact by citing cases reported in two works of recent history of the spontaneous combustion of the northern countryside under the summer heat ${ }^{19} \mathrm{He}$ then explains that the summer air in Northern regions like Muscovy is dense with humidity and thus hotter than the drier air in Southern climes. Bodin corroborates this conclusion with the common observation that fire burns hotter in wood than in straw and in metal than in wood, and he further illustrates his point by describing the practice of the sauna:

Those who want to heat baths rapidly at moderate expense pour water on the stones at the bottom of the bath which have been heated by fire: in a moment the closed room fills with the densest vapor, from which a violent heat is spread in the thick air: from which it is clear that the thickness of the air, excited by the vapor of the water, keeps the heat, while earlier it could not because of its fineness. (212)

Bodin never actually states the principle that denser things hold heat better than finer ones, but he amasses an original array of material on that theme and lays the foundation for a general "law" of nature, which he nonetheless never makes explicit. ${ }^{20}$

The Theatrum moves seamlessly from one topic to the next through the intermediary of themes or less substantive rhetorical devices, pursuing each topic or theme until the copia on that issue is exhausted. In Bodin's République and Methodus one can also detect the legacy of a commonplace book in the material that Bodin has gathered, but there he marshals his

${ }^{19}$ Bodin cites his sources here again because they are not well known: "Thomas Cromer in historia Polonica lib. 17; Sigismundus libr. in historia Moschovitarum." He is referring, with a number of minor errors, to Martin Cromer, Polonia sive de origine et rebus gestis Polonorum libri XXX (Cologne, 1589), XXVIII, 412; and Sigismund of Herberstein, Rerum Moscovitarum commentarij (Basel, 1556), 61.

${ }^{20}$ Bodin's reluctance to generalize to a "law of nature" as we might expect him to here and his unwillingness to dismiss reported facts as impossible because in violation of such laws (as we would be tempted to in many cases that he accepts) probably result in part from his strict adherence to the principle of divine omnipotence. 
copia in support of a few general arguments or themes born no doubt from his professional experience and lifelong reflection on questions of government and human history. In natural philosophy, where Bodin has less personal expertise, the shape of the original note-taking is more apparent in the final product: Bodin provides little overarching framework in which to relate his causal explanations one to the other. As a result he does not always confront his topical material thematically: contradictory explanations thus coexist in different parts of the work, as a few attentive contemporary readers pointed out. On page 284 , for example, Bodin explains that grafted trees yield more and sweeter fruit because of the more abundant sap called up to repair the wound, although a few pages earlier he had explained that older trees yielded sweeter fruit precisely because they were less full of sap (279). Is it the abundance or the absence of sap which causes sweetness in fruit? Bodin never addresses the general principle but provides contradictory evidence in the answers to different questions. Here Bodin's commonplace book, with its idiosyncratic set of interests, served to hide rather than uncover a thematic link.

The method of commonplaces can thus explain some of the puzzling features of traditional natural philosophy beyond the specific case of the Theatrum. ${ }^{21}$ Even if not all authors of traditional natural philosophy kept actual notebooks, the method serves as a metaphor for their way of creating physical knowledge. Although originally designed for notes from reading, the commonplace book easily accommodates material from nonbookish sources. It may record the origin of a fact (whether bookish or reported by a witness or an artisan) but treats each entry independently of its source, as potentially useful knowledge equivalent to every other entry. "Credulity" can therefore coexist with observation, new facts with traditional ones, without generating any internal tension. Similarly, the method of commonplaces explains how critical judgment can coexist with blatant inconsistencies. In sorting incoming information, the commonplace book offers opportunities for new critical confrontation of material; on the other hand the indefinite multiplication of separate headings can easily harbor contradictions which seem to belie the very critical faculties demonstrated elsewhere. As a tool for composition which opens many possibilities but requires none in particular, the commonplace book is

${ }^{21}$ In its general outline what I have called the method of commonplaces is as old as bookish natural philosophy itself: Pliny's Natural History offers a prime example of a source continually recycled through generations of texts, which is itself constructed from the compilation of primarily bookish tidbits of natural knowledge. On the origins and career of this classic of "notebook science," see G.E.R. Lloyd, Science, Folklore and Ideology: Studies in the Life Sciences in Ancient Greece (Cambridge, 1983), 139-44 and Charles Nauert, "Humanists, Scientists and Pliny: Changing Approaches to a Classical Author," American Historical Review, 84 (1979), 72-85. 
supremely tolerant of cognitive dissonance. And this tolerance is, I would argue, the key to the long survival of traditional natural philosophy. ${ }^{22}$

Just as Bodin's Theatrum grew out of a book of commonplaces, so too it served in turn as material to be entered in the commonplace books of its readers; the reception of Bodin's Theatrum through the first half of the seventeenth century is testimony to the continued vitality of the method. Three annotated copies which I have found show how diligent readers assigned topical and thematic headings to paragraphs and pages in their copies of the Theatrum, possibly as a first step toward entering the material into their notebook, in any case as a convenient index for future reference. ${ }^{23}$ One reader was especially attentive to Bodin's judgments of other authors: whom he praised and whom he criticized. All of them were alert to interesting "facts" which they flagged in the margin: both bookish (that the beams of the temple of Utica lasted 1200 years, probably taken from Pliny [278]) and garnered from direct experience (like the case of William of Orange who lost his sense of taste from a head wound, which Bodin reports having learned from William himself [460]). All of them also show some of the work of the commonplace book in the margins of their text: linking Bodin's passage to passages on the same topic in contemporary works that they had read (like Scaliger, Cardano, or the natural historians), to other passages in Bodin (thus pointing out contradictions like the one above), or to their own direct experience (when Bodin calls hares the fastest quadrupeds, one reader notes: "but when they are tired, dogs catch up with them" [405]). These marginalia reveal how the "facts" in Bodin's Theatrum were selected and absorbed into the mental networks of contemporary readers.

Some of Bodin's readers went on to cite the Theatrum-unfortunately not those whose annotations I have found. But citations of the Theatrum in the fifty years after its publication reveal the same process of selecting and reusing discrete facts from the text, as if through a commonplace book: the German natural philosophers who cite Bodin's Theatrum and recommend it to students for further reading starting in 1598 (notably Rodolph Goclenius, Bartholomäus Keckermann, and Clemens Timpler) ${ }^{24}$

${ }^{22}$ Cf. Edward Grant, "Aristotelianism and the Longevity of the Medieval World View," History of Science, 16 (1978), 93-106.

${ }^{23}$ These copies were annotated by Nicolas Granius, professor of natural philosophy at the universities of Rostock then Helmstedt (active at least 1596-1608) (at the Herzog August Bibliothek in Wolfenbüttel), by Isaac Casaubon (1559-1614) (at the British Library), and by an anonymous reader (in the personal library of Jean Céard). For the complete transcription of this last, richest set of marginal annotations see the appendix to my dissertation. I am most grateful to Jean Céard for the opportunity to study these notes.

${ }^{24}$ Rodolph Goclenius, annot. Physicae seu naturalis philosophiae Institutiones Cornelii Valerii Ultrajectini (Marburg, 1598); Bartholomäus Keckermann, Systema physicum (Danzig, 1610); Clemens Timpler, Physicae ... systema (Hanau, 1605). For more on these figures and their colleagues see Joseph Freedman, European Academic Philosophy in the 
were especially interested in including Bodin in their doxographies on traditional Aristotelian subjects and dwell on Bodin's unusual anti-Aristotelian positions on the causes of underground springs or comets or earthquakes. Like that one annotator, they selected primarily doxographical facts into their notebooks. On the other hand, natural historians like Johann Jonston used the Theatrum as a source of material for their own work. Both with and without naming his source Jonston takes numerous interesting "factoids" from Bodin: such as the distance of the reference star Prima Arietis from the equinox as reported by past astronomers, or the fact that vinegar penetrates the inner recesses of iron or that large emeralds are to be found in Lyon and Prague-Bodin had actually mentioned only Genoa and Magdeburg, but Jonston wrongly attributes these examples to Bodin. ${ }^{25}$ These natural facts are recycled almost fifty years after the publication of Bodin's Theatrum in Jonston's Thaumatographia naturalis which was reedited as late as 1665 .

The cycle of textual natural philosophy, processed through the commonplace book, thus continues unabated well into the seventeenth century. In the 1610s, for example, Alsted and Keckermann discuss the best ways to keep commonplace books. Keckermann in particular addresses Bodin's recommendations in the Methodus:

In the second book [Bodin] wants to contain the histories of natural things. His advice abut the physical commonplaces is skillful and fruitful... . Nonetheless his advice about the places of natural history is not free from confusion, in addition to the fact that the physical places are confused with those of astronomy and geography: just as the sciences are distinct from one another, so they each have their boundaries and peculiar method. ${ }^{26}$

Not for Keckermann then the potential which Bodin leaves for confronting material from different disciplines through thematic combinations; Keckermann recommends instead notebooks that mirror the academic disciplines, according to the Aristotelian principle that to each discipline its own method and material. The debate between what one might hastily call humanist and neo-scholastic visions of the commonplace book only reinforces my argument for the fundamental role of the method in the practice of traditional natural philosophy in this period.

But the method of commonplaces was not simply a tool of bookish

Late Sixteenth and Seventeenth Centuries: the Life, Significance and Philosophy of Clemens Timpler (2 vols.; Hildesheim, 1988).

${ }^{25}$ Jan Jonston, Thaumatographia naturalis (Amsterdam, 1633), I, ch. 3, 14 (cf. Theatrum, 563); IV, ch. 31, 196 (cf. Theatrum, 256); IV, ch. 21, 174 (cf. Theatrum, 233).

${ }^{26}$ Bartholomäus Keckermann, "De locis communibus in genere et in specie de historicis recte concinnandis, epistola scripta ad ... Dn. Gualterum ab Holden," appended to Gymnasium logicum. Lib. secundus, in Opera omnia quae extant (2 vols.; Geneva, 1614), I, 498. For Alsted's discussion of commonplaces see his Orator as cited above and the section on Didactica in his Encyclopedia (Herborn, 1630). 
natural philosophy that disappeared-later than some have thought, but which disappeared nonetheless - with the rise of "modern" science during the seventeenth century. Indeed the core of the method lives on, I would argue, in Francis Bacon's precepts for a new science. It would be foolish to ignore the very real differences between Bodin and Bacon: Bacon deplores for example precisely the cycle of bookish natural philosophy that we can trace in the making and reading of Bodin's Theatrum when he complains that by "superinducing and engrafting new upon old ... we would revolve forever in a circle with mean and contemptible progress."27 But what Bacon offers in place of traditional natural philosophy is a method of commonplaces applied in principle at least to the world itself rather than to books.

Bacon praises the practice in the Advancement of learning:

For the disposition and collocation of that knowledge which we preserve in writing, it consisteth in a good digest of common-places; ... I hold the entry of common-places to be a matter of great use and essence in studying, as that which assureth copie of invention, and contracteth judgement to a strength. But this is true, that of the methods of common-places that $I$ have seen, there is none of any sufficient worth: all of them carrying merely the face of a school, and not of a world; and referring to vulgar matters and pedantical division, without all life or respect to action. ${ }^{28}$

The New Organon presents Bacon's new tool for scientific investigation, which turns out to be just such a method of commonplaces "carrying the face of a world" and designed for "action." The first step is to collect and present to the understanding all known instances of a phenomenon, combined with instances where it is absent or present to varying degrees; the next step, induction, proceeds by the systematic confrontation of the material arranged in tables: the prerogative instances revealed in this confrontation help to reach flawless general principles. Bacon's ideal is a method of natural commonplaces derived from direct observation which abides by strict guidelines for the thematic sorting and confrontation of material gathered topically. ${ }^{29}$ In practice, however, Bacon was in too great a hurry to follow his rules carefully: the result is an unfinished work which shares with Bodin's Theatrum a close proximity to the commonplace book from which it derives, and it is a traditional Renaissance commonplace book at that. As Graham Rees has shown, Bacon's last work, the Sylva sylvarum (1626), juxtaposes bookish with directly observed facts, com-

\footnotetext{
${ }^{27}$ Francis Bacon, New Organon, ed. Fulton H. Anderson (Indianapolis, 1960), I, aphorism 31, 46.

${ }^{28}$ Francis Bacon, The Advancement of Learning, ed. Arthur Johnston (Oxford, 1974), Book II, ch. 14, 129-130.

${ }^{29}$ For a similar point see Paolo Rossi, Francis Bacon, from Magic to Science (Chicago, 1968), ch. 6, especially 207-14; on Bacon's method more generally see Lisa Jardine, Francis Bacon: Discovery and the Art of Discourse (Cambridge, 1974), ch. 4.
} 
bines credulity and experimentation, critical judgment and what appear to us as the most obvious inconsistencies. ${ }^{30}$ While the New Organon places the method of commonplaces at the center of a bold new program for natural investigation, the Sylva sylvarum, one of the most widely reprinted of Bacon's works (and regrettably the least studied by historians of science), reveals the long career of the Renaissance book of natural commonplaces as exemplified in Jean Bodin's Universae naturae theatrum. ${ }^{31}$

Harvard University.

${ }^{30}$ Graham Rees, "An Unpublished Manuscript by Francis Bacon: Sylva Sylvarum Drafts and Other Working Notes," Annals of Science, 38 (1981), 377-412; see also Mordechai Feingold and Penelope Gouk, "An Early Critique of Bacon's Sylva sylvarum: Edmund Chilmead's Treatise on Sound," Annals of Science, 40 (1983), 139-57, e.g. 151.

${ }^{31}$ In addition to the debts acknowledged above, I am grateful to Anthony Grafton for many helpful readings of this work and to Roger Chartier for the opportunity to present it at the Centre Alexandre Koyré in Paris. 